\title{
O LUTO INTERMINÁVEL: BARTHES E A PRESENÇA AUSENTE \\ THE NEVER-ENDING MOURNING: BARTHES AND THE PRESENCE OF ABSENCE
}

\author{
Alamir Aquino Corrêa*
}

RESUMO: Nesta digressão, buscarei evidenciar no trabalho de escrita de Journal de Deuil, de Roland Barthes, menos acadêmico e talvez mais denso ainda, o papel aflitivo da presença da ausência que deu origem ao livro La Chambre Claire. Essa falta/ausência se torna nele uma dolorosa infidelidade póstuma, ao escrever sobre o seu sentimento e sentir-se ético em relação a sua mãe; esse luto sofrido por Barthes como acontecimento interminável se torna possível pela compreensão da presença da ausência.

PALAVRAS-CHAVE: Roland Barthes, Journal de Deuil, luto, ausência, perda.

ABSTRACT: In this digression, I try to show through reading Roland Barthes' writing of the Journal de Deuil, a bit less academic and maybe even denser than before, the afflictive role of presence of absence which ultimately spawned La Chambre Claire. This lackness/absence becomes in him a painful posthemous infidelity, for he writes about his feelings and about being ethical towards his mother; this mourning as experienced by Barthes as never-ending becomes possible through the understanding of the presence of absence.

KEYWORDS: Roland Barthes, Journal de Deuil, mourning, absence, loss.

\footnotetext{
* Universidade Estadual de Londrina, Londrina, Estado do Paraná, Brasil. Doutor em Literaturas Hispânicas pela Indiana University (1990), Professor Associado de Teoria da Literatura e Literatura Brasileira do Departamento de Letras Vernáculas e Clássicas. E-mail: alamir@uel.br.
} 



\title{
O LUTO INTERMINÁVEL: BARTHES E A PRESENÇA AUSENTE
}

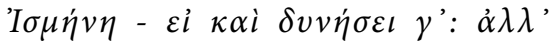 \\ $\dot{\alpha} \mu \eta \chi \alpha \dot{\alpha} v \omega v \dot{\varepsilon} \rho \tilde{\alpha} \varsigma$. (90) \\ Ismênia - Se tu o fizeres... mas o que \\ desejas é impossivel.
}

A recente publicação de Journal de Deuil (2009), de Roland Barthes (19151980), escrito entre 26 de outubro de 1977 e 21 de junho de 1979, trouxe um novo olhar sobre a questão do luto e sobre o seu importante La Chambre Claire (1980), escrito de 15 de abril a 3 de junho de 1979. Essa obra trata do efeito emocional da fotografia, através dos conceitos geminados do studium (interpretação da fotografia) e do punctum (afetividade causada pela fotografia), tomando como fundamento os termos de seu luto pela mãe, falecida em 25 de outubro de 1977. Muitos têm percebido a obra como além de um texto teórico fundamental para o estudo da fotografia; ela seria um romance discursivo, ou seja, um conjunto fragmentado de percepções a lidar com um fato essencial, o luto por sua mãe e a modificação de seu olhar sobre as coisas e o mundo, tangenciando o mundo ficcional.

O Journal de Deuil é uma publicação póstuma, organizada por Nathalie Léger, constituído de 330 fichas com notas, sentenças, por vezes quase haicais, uma escrita sobre o futuro inalcançável, tendo como pano de fundo a leitura de Proust; o Journal de Deuil tem também uma quase ficcionalidade, 
com uma grande personagem ausente e um inconformado narrador. A tarefa do luto encontrável nessa obra de Barthes atinge possivelmente o nível mais absoluto da consciência de um eu, aquele constituído por um dilema fundamental entre a vida e a morte, diferente do outro eu, morto também com a morte da mãe; é um discurso de aceitação da própria morte, pois que irreconciliáveis a memória e a ausência.

\section{Amekhanon erais}

Na cena inicial da peça de Sófocles, Antígona se mostra avessa à decisão do Estado, encarnado por Creonte, pendendo para o erro (harmatia), pois que eticamente se vincula a seu irmão Polinice pelas razões da phillia (família), mesmo que esta faça parte da polis (Estado). A fala de sua irmã Ismênia, que serve de epígrafe a este texto, recupera a proposição de pavor, quando diz que o desejo de Antígona lhe causa calafrios, e assume como impossível, impraticável e inalcançável estar quites com a responsabilidade familiar em prejuízo de sua responsabilidade para com o Estado.

Ismênia representa o contexto moral prevalente, aquilo que é recompensado no contrato social existente. Antígona, por outro lado, é a representação do instante cognitivo particular, a bem da verdade já previsto como o não-ser, ou, o além-do-ser. Se o passado é representado em Ismênia, revigorado como o que é possível, Antígona é o dilema anterior à decisão do passado - em outros termos, torna-se concreta a separação entre o aceitável, a norma do Estado, e o inaceitável, o indesejável, o impraticável, o impossível - a não-norma do Estado.

Mais do que ir contra a moral do Estado, Antígona é o contraponto, a que veio antes do estabelecimento da moral prevalente. No contexto familiar, a phillia viria antes da polis; no contexto de uma verdade universal, Antígona representa uma emoção que se quer ação anterior e mais básica - porque o ser e o não-mais-ser se tornam alicerces da própria existência e constituição do eu e do outro, antes da articulação do "nós". Ao desprezar a moral ou ao sobrepujá-la, no pensamento de Ismênia, Antígona recupera algo que é mais forte do que o conhecimento da tradição, ela precisa assumir tal responsabilidade para que haja justiça, em uma situação que o filósofo judeu-lituano-francês Emmanuel Levinas denominou como a obsessão do homem:

Dans la proximité de l'autre, tous les autres que l'autre, m’obsèdent et déjà lobsession crie justice, réclame mesure et savoir, est conscience. Le visage obsè- 
de et se montre: entre la transcendance et la visibilité/invisibilité. La signification signifie dans la justice, mais aussi, plus ancienne qu'elle-même et que légalité par elle impliquée, la justice passe la justice dans ma responsabilité pour l’autre, dans mon inégalité par rapport à celui dont je suis l’otage. (1996: 246). ${ }^{1}$

Na proximidade do outro, todos os outros além do outro me sitiam e já a obsessão grita justiça, exige medida e saber, é consciência. O rosto sitia e mostra-se: entre transcendência e a visibilidade/invisibilidade. O significado se significa na justiça, mas também, mais antigo que ela própria e que a igualdade por ela implicada, a justiça passa a ser a justiça na minha responsabilidade para com o outro, na minha desigualdade em relação àquela do qual sou refém.

A decisão de Antígona, sob o prisma da responsabilidade, a faz obrigada a ser diferente, a despeito das normas, do passado, do contrato (SPARGO, 2004: 5) - é a única maneira de ela se manter humana, de ser mais que o observador passivo. Antígona só se perfaz como possível quando deixa de ser o que dela se espera - sua impossibilidade, sua impraticabilidade, sua transgressão estão no limiar do não-ser e, ao mesmo tempo, na base da construção do dever-ser. É quando se percebe que há algo de absolutamente impossível que precisa se tornar possível, o instante em que nos encontramos humanos, quando efetivamos não a legalidade, mas a justiça. A verdade se torna, assim, maior que a tradição, pois a resposta de Antígona se faz ética diante do outro, o morto, a despeito da obrigação moral para com o Estado. Mais ainda, esta obrigação pré-disposta é só dela e não dos outros, pois cabe somente a ela (por extensão, a nós leitores/expectadores que a incorporamos em algum instante e somente quando queremos/podemos/devemos ser Antígona) a responsabilidade de ser o que não se é. Mas, isto posto, é possível tratar de uma ética do luto?

\section{Infidelité phostume}

Em "Le temps retrouve", de À la Recherche du Temps Perdu de Marcel Proust, há um trecho especialmente importante para o presente texto. Refiro-me ao episódio "Matinée chez la princesse de Guermantes", em que se lê:

\footnotetext{
${ }^{1}$ Nota bene: todas as traduções são nossas.
} 
Tous ces êtres, qui m’avaient révélé des vérités et qui n'étaient plus, mapparaissaient comme ayant vécu une vie qui n’avait profité quà moi, et comme s'ils étaient morts pour moi. Il était triste pour moi de penser que mon amour auquel javait tant tenu, serait dans mon livre, si dégagé d'un être, que des lecteurs divers l'appliqueraient exactement à ceux qu'ils avaient éprouvé pour d'autres femmes. Mais devais-je me scandaliser de cette infidélité posthume et que tel ou tel pût donner comme objet à mes sentiments des femmes inconnues, quand cette infidélité, cette division de l'amour entre plusieurs êtres, avait commencé de mon vivant et avant même que jécrivisse? (1954: 3.902).

Todos esses seres, que me revelaram verdades e que não estavam mais aqui, pareciam-me que haviam vivido uma vida da qual só eu aproveitei, e como se tivessem morrido por mim. Era triste para mim pensar que meu amor, a quem eu tinha tanto me dedicado, estaria em meu livro tão desligado de um ser, que leitores diversos aplicariam exatamente ao que tinham sentido por outras mulheres. Mas eu devia me escandalizar com essa infidelidade póstuma e que este ou aquele pudesse atribuir o objeto de meus sentimentos a mulheres desconhecidas, quando essa infidelidade, essa divisão do amor entre diversos seres, principiara durante a minha vida e antes mesmo que eu escrevesse?

Leio o trecho como se os mortos com quem convivêramos deixassem-nos sempre as verdades que só servem a nós. Por mais que possamos estar a pensar neles, como se continuassem a viver através de nós, fica a sensação de que eles não mais são, que deixaram de ser mesmo que os mantenhamos dentro de nós. Nossa responsabilidade em relação a eles parece cessar desde antes, como se todos nós, mortos e deixados (herdamos a memória do morto e somos responsáveis pelos compromissos com o de cujus) ou sobreviventes, pois vivemos além da vida do morto e também (não necessariamente) com alguma culpa pela mesma experiência - uns mortos e outros não, fizéssemos parte de um contrato tão essencial que não precisa ser escrito. Ao tratarmos deles em nossas vidas, nós enquanto deixados, é como se fôssemos infiéis, como se descumpríssemos o contrato.

Ao lidarmos com o luto, em tese, se tornaria benéfico restabelecer a normalidade - isto é -, o contato com os vivos, respeitando a norma social prevalente. A memória/lembrança do morto deveria servir para o crescimento do grupo; o ato do luto se torna assim comemorativo, aquilo que desejamos lembrar - construção de monumentos, porque representações de nossa mo- 
ral, um novo querer ser. Na proposição de Freud sobre o luto, em Trauer und Melancholie, a dor ou o pesar pela morte do outro nega-nos a fruição do prazer (em essência, o contato com os outros vivos):

Die schwere Trauer, die Reaktion auf den Verlust einer geliebten Person, enthält die nämliche schmerzliche Stimmung, den Verlust des Interesses für die Außenwelt - so weit sie nicht an den Verstorbenen mahnt, - den Verlust der Fähigkeit, irgend ein neues Liebesobjekt zu wählen - was den Betrauerten ersetzen hieße, - die Abwendung von jeder Leistung, die nicht mit dem Andenken des Verstorbenen in Beziehung steht. Wir fassen es leicht, daß diese Hemmung und Einschränkung des Ichs der Ausdruck der ausschließlichen Hingabe an die Trauer ist, wobei für andere Absichten und Interessen nichts übrig bleibt. Eigentlich erscheint uns dieses Verhalten nur darum nicht pathologisch, weil wir es so gut zu erklären wissen (1917: 289).

O luto pesado, a reação à perda de alguém amado, contém a mesma inclinação penosa, a mesma perda de interesse pelo mundo externo - vez que esse não evoca aquele alguém -, a mesma perda da habilidade de adotar um novo objeto de amor - que seria chamado a substituí-lo - e a mesma inibição de atividade que não esteja relacionada à memória daquele que se foi. Constatamos facilmente que a inibição e a restrição do ego são a expressão de devoção exclusiva ao luto, que nada deixa a outros propósitos ou interesses. Realmente, essa atitude não nos parece patológica somente porque sabemos explicá-la tão bem.

Nesse instante do enfrentamento da perda de alguém, revigora-se o dilema vivido por Antígona, a observação ou a participação. O morto parece esperar de nós algo que se torna impossível, até mesmo pela circunstância imposta pelo contrato social; a construção do monumento não interessa ao morto, sim aos vivos. Enquanto atos elegíacos, a oração fúnebre e o elogio fúnebre exigem o rompimento do silêncio que o morto nos requer, embora nossa relação ética com o morto exija a impossibilidade de manifestação, ou como disse Jacques Derrida em sua homenagem a Paul de Man: "Parler est impossible, mais se taire le serait aussi, ou s'absenter ou refuser de partager sa tristesse" (1985: 14) ou "Falar é impossível, mas se manter silente também seria, ou se abster ou se recusar a compartilhar da tristeza”. 
Ao recuperar Proust e o fazer literário, creio que é possível lidar com o mundo acadêmico, onde raramente se percebe o ser-para-a-morte, crível, pleno de emoções, alguém que sofre e está consciente daquele que não mais é. A tradição nos impõe a busca da imortalidade, também elegíaca, quando o acadêmico quer se tornar um monumento do qual queremos nos lembrar. É assim que levemente proponho a leitura de "Les morts de Roland Barthes", de Jacque Derrida, como monumento, especialmente porque o filósofo escolheu como forma textual o discurso fragmentado por pedras (sinais gráficos), como um ritual funerário em que o silêncio se mescla com as perquirições ou a maneira de poder voltar a ele mesmo e a Barthes. Nesse texto, apesar da esperada emoção, Derrida é analítico e racional, ponderando sobre as lições e contribuições de Barthes, lembrando daquele que não mais é. Sua grande preocupação ao longo de sua memória de Barthes é a infidelidade possível e "indecente".

\section{Plus de lumière}

Em um dos fragmentos iniciais de seu texto publicado em homenagem póstuma a Roland Barthes, Derrida diz: "Plus de lumière, pour laisser à penser, laisser à désirer" (1981: 270) ou "Não há mais luz para deixar algo a pensar, a desejar". Essa sensação é talvez a mais complicada no enfrentamento da morte, quando o deixado se vê a contemplar o vazio, a ausência, a não-presença. A escrita de textos elegíacos, malgrado ser reflexão após o fato (a morte) e, por isso, com o seu quê de proposta de imortalidade, está pautada por um grande dilema, o ser diante do morto e o ser diante dos outros. Parece que não há dificuldade, mas ela existe seriamente, quando aquele que olha o morto fica entre a ideia do testemunho e aquela da observação, uma sofrida e outra de desprendimento emocional. Quer dizer, quando a simpatia se torna algo sobre aquele que morre e quando se transforma em uma emoção catártica; entretanto, ambas nada servem ao que morreu. Ao deixado, fica a sensação da falta de continuidade que ele esperava e que se vê dela privado.

Está-se, pois, a lidar com a emoção enquanto substituto ou provocação da ação real. $O$ deixado quer fazer ou gostaria de fazer algo que impedisse a morte do outro, pois que prevê a falta de luz. Nesse instante, ocorre também a culpa, enquanto emoção, daquilo que precisaria ser evitado, algo que aflige por demais os profissionais da saúde. É a compreensão de nossa fragilidade, por incapacidade de ter controle sobre o que está a aconte- 
cer com aquele que morre. Há como que uma rendição - quem sobrevive "deixa ou permite" que o outro morra; mas sofre tremendamente, pois lhe sobressai a antecipação do sentimento da perda/ausência. No luto, esse sentimento já está na área do distanciamento, permitindo que se perfaça a ficcionalidade; nesse momento, a partir da reflexão, podemos nos dirigir ao morto, assumir fingidamente a sua continuidade conosco, esquecer ou delir eventuais rusgas e desavenças, exercitar por meio dessa emoção um substituto da ação real, como apontei acima. O luto se constitui de um exercício ficcional, quando aos poucos nos damos conta de que há outras coisas, há outro mundo, há algo além do morto. A tarefa do luto é essa negociação individual do eu em relação ao outro, mas sempre tangida pela sensação horrível de uma possível infidelidade póstuma.

Logo no início do seu texto, Derrida se pergunta sobre a utilidade ou a viabilidade da elegia, afinal sua fala não atingirá o destinatário, pois Barthes não mais está ou é: "Pour lui, cela semble dire que je voudrais aussi lui dédier ces pensées, les lui donner, les lui destiner. Or elles ne lui arriveront plus, c'est à partir de là que je dois penser, elles ne peuvent plus lui arriver, arriver jusqu’à lui si même l'avaient pu de son vivant” (1981:269), ou "Para ele, parece dizer que eu gostaria de dedicar esses pensamentos a ele, dá-los a ele, destiná-los a ele. Entretanto eles não chegarão mais a ele, é desse ponto de partida que devo pensar, eles não podem mais chegar a ele, chegar até ele mesmo que se tivessem podido enquanto vivia”. A seguir, pergunta se ao mantermos alguém vivo dentro de nós é a melhor maneira de ser fiel ao morto (1981: 270). Derrida procurava ser como Barthes, em ato mimético, enquanto um dever e uma tentação. O dever é a fidelidade, o respeito, de tal sorte que o morto fale por sua voz, como se tal atitude pudesse ser o caminho para tornar o morto presente, fielmente representado; mas se representado, não há a possibilidade da fidedignidade da existência, logo uma negação, um assassínio, uma injustiça, uma indecência: "Je cherchais comme lui, comme lui, et dans la situation où j’écris depuis sa mort, un certain memétisme est à la foi le devoir (le prendre en soi, s'identifie à lui pour lui laisser la parole en soi, le rendre présent et le représenter dans la fidelité) et la pire des tentations, la plus indécente, la plus meurtrière, le don et le retrait du don, essayez de choisir" (DERRIDA, 1981: 272), ou "Eu buscava como se fosse ele, come ele, e na situação onde eu escrevia depois de sua morte, um certo mimetismo é a um tempo o dever (tomá-lo em si, identificar-se com ele para deixá- 
-lo falar dentro de si, fazê-lo presente e representá-lo com fidelidade) e a pior das tentações, a mais indecente, a mais mortífera, o dom e a retirada do dom, tentem escolher".

Como é então possível ser ético em relação ao morto? Afinal o morto já não é, já não responde. É possível fazer viver o morto em nós? O que dele vive em nós? O que somos se temos o morto em nós? A elegia, a oração fúnebre, o elogio póstumo, através deles é possível pedir perdão ao morto? Como Ismênia, Derrida afirma ser impossível a escolha:

Deux infidélités, un choix impossible: d'un côté ne rien dire qui revienne à soi seul, à sa propre voix, se taire ou au moins se faire accompagner ou précéder, en contrepoint, par la voix de l'ami. Dès lors par ferveur amicale ou reconnaissante, par approbation aussi, se contenter de citer, d'accompagner ce qui revient à l'autre, plus au moins directment, lui laisser la parole, s'effacer devant elle, la suivre, et devant lui (1981: 276).

Duas infidelidades, uma escolha impossível: de um lado nada a dizer que vá até ele mesmo, a sua própria voz, calar-se ou pelo fazer-se acompanhar ou preceder, em contraponto, pela voz do amigo. Assim, por fervor de amizade ou de reconhecimento, por aprovação também, contentar-se em citar, em acompanhar aquilo que vem até o outro, mais ou menos diretamente, deixar-lhe a fala, anular-se diante dela, segui-la, e diante dele.

Estar diante do morto é obrigar-se ao silêncio, pela impossibilidade do diálogo; reconhecê-lo obriga também anular-se, o morto em nós, para que ele fale. Mas isso é impossível, é como permitir que o morto desapareça pelo silêncio e, ao mesmo tempo, dizer coisa alguma ao ser fiel ao morto.

Segundo Derrida, uma percepção póstuma pode acontecer de três formas, ao enfrentar-se com o morto: esse morto antes de o lermos, os mortos que lemos enquanto eram vivos e aqueles que morrem e que são os que conhecemos e amamos enquanto vivos (1981: 279). Volta-se, necessariamente, ao conflito essencial da proximidade do eu com o outro que morreu. Antígona se mostra próxima de Polinice; mesmo também sua irmã, Ismênia, precisa estar distante para que continue a olhar os outros que estão vivos. A separação das emoções e das ações em Sófocles mostra-se trágica, mas cristalina. Em Derrida, há o grave questionamento por aquele que percebe que o silêncio é decente, justo, possível, mas há, também, de lidar com o mor- 
to, aprender com ele, com o que era, com uma possibilidade de escolha de vigência da memória. Mas conclui Derrida que o silêncio, talvez a melhor forma de nos aproximarmos com o morto, também se torna insultuoso: “Mais le silence alors? N'est-ce pas une autre blessure, une autre injure? - A qui? - Oui, à qui faisons-nous présent et de quoi? Que faisons-nous quand nous échangeons ces discours? A quoi veillons-nous? A annuler la mort ou à la garder?” (1981: 280), ou “- Mas o silêncio agora? Não é outro insulto, uma outra injúria? - A quem? - Sim, a quem estaremos presenteando e com o quê? O que fazemos quando intercambiamos esses discursos? Quem velamos? Negar a morte ou guardá-la?”.

Essas percepções elegíacas criam uma ficção, uma possibilidade de estarmos com o morto quando ele já não é. Quer-se pedir perdão, algo impossível, inalcançável, impraticável, mas a única face que temos é a do morto em nós, como se fôssemos dele o seu espelho. Ao fazermos isso, somos também infiéis, pois lhe negamos a possibilidade de ser, e damos outra construção a nós mesmos, aquela de sermos quando o morto está em nós, nosso eu imerso em ou contendo o outro. Talvez aqui a pior das infidelidades, quando dizemos que lamentamos o morto ausente e, em verdade, elogiamos a nossa própria nova essência, constituída de nós, e a presença da ausência daquele que nos deixou.

A elegia, na sua forma lamentadora em relação à morte, manifestação enlutada, pode ser percebida geralmente como tripartite: a expressão dolorida em razão da morte do outro, o enfrentamento da mortalidade que nos aproxima do morto (algo que dá a todos tanto uma carga de dignidade quanto de expiação da culpa por permanecermos vivos e o outro não), e uma consolação da inevitabilidade da morte. Esse fecho se baseia na possibilidade de um outro mundo e da cessação da dor no mundo em que estamos, na consciência da renovação dos agentes como uma lei social e natural, e na percepção racional do valor da vida e de sua duração.

Na modernidade, outras cargas emotivas são agregadas à elegia como a noção da perda e da sobrevivência, a possibilidade da memória e da ansiedade pela imortalidade, o papel representado pelos deixados e pelos sobreviventes (aqui os dois conceitos são importantes) no aproveitamento do passado. A perda e a ausência se tornam os grandes motivos elegíacos; o foco deixa de ser o morto, seu preparo para a vida além-da-morte e seu legado. O deixado, o sobrevivente, o testemunho, o dever futuro, a tarefa do luto, talvez em um exagero de egoísmo, passam a ter maior ou total im- 
portância na elegia moderna, que trata de perdas além da morte como se pode perceber na angústia de Consuela em The Dying Man, de Philip Roth (2001); interessantemente, ao ser levado para o cinema por Isabel Coixet, o pequeno romance teve o seu título transformado em Elegy. Os narradores, as famílias do(s) morto(s), o passado presente na memória, o eu que se faz diferente, deixando de ser o eu para se tornar um novo eu a lidar com a memória e com o momento em que se faz eu-e-o-outro, todos esses parecem deixar o morto como fundamento e passam a considerar a memória e sua durabilidade como importante.

O lamento pelo morto cede espaço para a dúvida, para a ironia, para o deslocamento, como se a definição ou "definitividade" da morte do outro impedisse a efetivação de seu lamento. A dor migra para a ausência, para o eu que precisa enfrentar a si mesmo; não há mais um mundo perfeito, futuro e consolatório. O passado que está ausente se torna parte do questionamento, por sua grave responsabilidade na conformação do tempo presente. Está-se, pois, a lidar com o tempo que se foi (temps perdu), com o tempo futuro a ser encontrado (um temps retrouve). Essa passagem, a tarefa do luto, dolorida, é não pelo morto que já não mais é, mas por precisar o eu compreender o que foi e o que precisa ser. A proposição de Paul Ricoeur (1965) sobre o processo do luto parece apropriada para explicar a acomodação necessária e ética do deixado em relação ao mundo que era e as decisões necessárias e apropriadas no mundo que sobrevive.

\section{La nature de l'absence}

Enquanto somos - eu e o outro -, estabelecemos, conforme Derrida (1994), o pacto de assumirmos que um de nós morrerá antes, é a política da amizade, que também existe como a política da família. Enfrentamos a vida à espera do momento em que seremos não mais eu e o outro, seres distintos, e passaremos a ser eu-e-o-outro, diferente dos dois anteriores, com uma memória e uma responsabilidade completamente conflituosa, na esteira de Freud, em angústia pela necessidade de nos mantermos eu-e-o-outro e pelo desejo de voltarmos a ser um "eu" ou um "outro". Nesse instante, em que enfrentamos a tarefa do luto, há de se lidar com algo um tanto diferente do enfrentamento da morte que irá acontecer como descrito por Liev Tolstoi em Смерть Ивана Ильчча [A morte de Ivan Ilitch], ou por Elizabeth Kübler-Ross em On Death and Dying. O luto é a morte acontecida, quando precisamos enquanto deixados compreender nosso papel diante do morto 
e diante de todos os outros, além de precisarmos nos reencontrar enquanto eu, estabelecendo outro e novo espelho.

No instante em que escrevo esta parte, por circunstância familiar e profissional, estou sozinho, frio e calor alternam-se na primavera da costa nordeste americana; raramente saio do apartamento onde moro, exceto para as visitas a bibliotecas e para suprir necessidades domésticas inadiáveis. Estou a viver também com uma ausência dolorida, mas em nada parecida com a ausência existente em o Journal de Dueil, onde Barthes descreve a solidão como um processo necessário para lidar com o mundo, ou seja, algo além do eu. Se sua mãe era-lhe transparente $\left(29 / 10 / 77,3^{a}\right.$ nota $\left.{ }^{2}\right)$ para que pudesse escrever, quando ela não mais é (aqui preciso enfatizar a noção do ser com o uso do tempo presente), Barthes parece sentir a impossibilidade da escrita enquanto vive essa nova solidão, essa outra ausência é, em verdade, uma presença da ausência; a anterior não era o silêncio advindo da ausência de sua mãe e, sim, aquele resultante da presença que se fazia ausente ou de uma presença transparente. Essa presença da inaceitável ausência, que o incomoda tanto, faz Barthes refletir sobre várias coisas; entre elas estão o luto, o tempo, a futuromania, o diário enquanto tarefa do luto, os outros, o novo eu que precisa surgir, o eu anterior e o outro (sua mãe), que já não é e foi em momento anterior, o eu-e-o-outro, o contato dele com os outros, a homossexualidade. Por conta da ambiguidade das referências, esse último tema não será tratado aqui; registro, entretanto, haver identificado as seguintes notas menos veladas: 27 ( $1^{\text {a }}$ nota) e 29/10, 5/12, em 1977; 16/1, 18/4, 12/6 e 27/7, em 1978.

Assim, antes de propor uma leitura não linear e tampouco exaustiva do Journal du Deuil, registro também essa outra nota pessoal, que talvez diminua muito o caráter acadêmico que se espera em um artigo. Da mesma maneira que Derrida, mutatis mutandis, manifesto a imensa dificuldade crítica para lidar com a obra de Barthes. Seu texto é daqueles da segunda categoria proposta por Derrida. Não convivi obviamente com Barthes e leio seu texto na grande distância espaço-temporal que nos separa, mesmo que tenha lido parte de sua obra ainda enquanto ele era vivo. Apesar desse vetor, sinto-me constrangido, lendo seu texto sem a emoção, apenas como observador; talvez percebê-lo como literário - verdade que existe baseada na emoção possível do outro - seja a maneira para lidar com seu texto, sem

\footnotetext{
${ }^{2}$ Nota bene: usarei as datas das anotações de Barthes de forma a facilitar a perspectiva cronológica das anotações e a consulta, independendo da edição.
} 
invadir a privacidade da pessoa Roland Barthes. Somente vendo seu texto como uma narrativa literária autodiegética, posso sentir-me ético em relação a ele, respeitando-o com o silêncio necessário e, paralelamente, rompendo esse último, de forma que possa propor uma compreensão do seu processo de luto.

A presença da ausência pode ser caracterizada pelo conjunto de circunstâncias e de reflexões que passou a fazer falta ou existir no mundo de Barthes: não mais ouvir a voz da mãe e pensar nela como alguém que não mais é (29/10/77, $1^{\text {a }}$ nota), o vazio da relação de amor (9/11/77), a natureza abstrata da ausência $\left(10 / 11 / 77,2^{\mathrm{a}}\right.$ nota), trabalhar na solidão vinculado à presença da ausência $\left(28 / 11 / 77,2^{a}\right.$ nota), ausência de sentido da vida (11/12/77), o surgimento de um "eu" que não se esperava, menos nobre e generoso (12/2/78, $1^{\text {a }}$ nota), estar sozinho no trabalho onde ela não tinha presença $\left(10 / 5 / 78,2^{\text {a }}\right.$ nota), o intolerável mundo dos outros e o que ele precisa: um exílio gentil - "l'absence de monde (de mon monde)" ou "a ausência do mundo (do seu mundo)" (21/7/78), o desapontamento e o desconforto com a convivência em outros lugares (1/8/78), o nunca mais ser de maman (1/8/78, $2^{\text {a }}$ nota), viajar é estar separado dela mesma, que ela não mais é (18/8/78, $1^{\text {a }}$ nota), a falta de desejo de construir algo novo - nenhum amor, nenhuma amizade (17/1/79). Há um ponto de separação dessa ausência, quando Barthes se dá conta de que pode se afastar do luto (logo de maman) ao ser capaz de viver sem ela, morar no apartamento, trabalhar, sair (22/2/79). A solidão provocada e buscada por Barthes dá substância a essa ausência presente, que a traduz como não ter ninguém a quem se possa dizer que estará de volta ou a quem se possa chamar dizendo a palavra Voilá como código constante de sintonia entre os dois (5/11/77), "voilá, je suis rentré" ou "voilá, estou em casa" $\left(11 / 11 / 77,1^{\text {a }}\right.$ nota), como viajar e querer voltar mesmo sabendo que ela não está esperando por ele, para onde tudo lhe é familiar e esse tudo diz a ele que ela não mais está lá (24/7/78).

A razão dessa vinculação forte de Barthes com sua mãe, que lembra a ética do compromisso de Antígona para com Polinice, também encontra registro na memória (em poucos momentos) de vida da mãe: ele se dá conta de que ela foi tudo para ele durante a doença e antes foi menos ou ele não poderia ter escrito sua obra $\left(29 / 10 / 77,3^{\text {a }}\right.$ nota); nesta, ela se faz presente conforme o testemunho de leitores (14/11/77, $2^{\text {a }}$ nota) (e antes de La Chambre Claire); a descrição da neve que cai em Paris que ela via ou da qual ele fazia a descrição $\left(12 / 2 / 78,2^{\text {a }}\right.$ nota) ou quando ele estava doente e não ia para a 
escola e ela cuidava dele (16/2/78); a caixa de pó-de-arroz no filme The Little Foxes a lembrar-lhe a infância, e anota Barthes: Eu estou aqui, como se ela falasse com ele (10/4/78); o medo que teve de perdê-la (25/5/78); a presença dela no que ele escreveu (31/5/78); a vontade de morrer para reencontrá-la (6/7/78); toda a vida juntos: "j’ai eu un plaisir à être avec mam" ou "foi um prazer estar com mam” (21/8/78, $5^{\text {a }}$ nota).

Não se quer, obviamente, fazer qualquer exercício amador de psicanálise, ao enfatizar a dor causada pela morte e pelas lembranças do tempo que se foi; talvez essa proximidade possível pela franqueza amoldável e gentil de Barthes, que Derrida denominava como souple ou como virtude de souplesse (1981: 273), ou seja, um estilo dócil, complacente, acomodador, é que permite aproveitar-se de sua emoção para tentar entender seu registro sobre a falta que lhe faz sua maman e o quanto ela foi importante em sua vida. Bastante consciente disso ele se mostra ao registrar a sua angústia entre a responsabilidade sua para com a memória da mãe e a necessidade pungente e imediata de reconexão com o mundo dos outros, como se pretende demonstrar adiante.

\section{Sehnsucht}

A tarefa do luto está nele dividida em duas partes em conflito, aquela que permite vislumbrar uma coexistência dele com a memória que lhe é inerente (que chamei de eu-e-o-outro) e aquela da criação de um novo eu, ao par de uma futuromania. Em várias línguas, tem-se buscado estabelecer palavras que possam dar significado ao conjunto de emoções causadas pela ausência que se faz presente na dor do deixado ou daquele que perdeu algo. Por muito tempo, tem-se tido certa vanglória da língua portuguesa pelo contexto da palavra saudade; sem desprezá-la, quero usar aqui o conceito do sehnsucht, palavra alemã composta de das sehnen (anseio) e die sucht (um apego) - quase intraduzível, que se aproxima muito da palavra saudade, mas que indica um estado emocional de busca ansiosa e inconsolável por algo que não se sabe exatamente o que é; penso que a saudade tem o seu lado consolatório, que não existe em sehnsucht. Quero usá-la como descritora do conjunto de emoções vividas por Barthes ao construir ou se dar conta de que não é mais um eu, e sim um eu-e-o-outro.

A primeira angústia que surge com todos que perdem alguém é como viver onde já não mais está quem se foi (31/10/77, $2^{\text {a }}$ nota) e como fazer a divisão entre a lide diária e a angústia da ausência (situação que, para Barthes, 


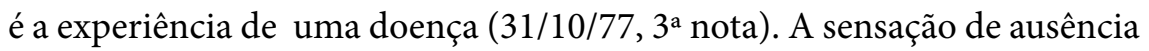
se transforma quando se passa a pensar como o outro ou o que o outro gostaria que se fizesse (3/11/77); Barthes chega ao ponto de agir como se fosse sua mãe ao cuidar do apartamento: "Eu sou eu mesmo a minha própria mãe" $\left(4 / 11 / 77,4^{a}\right.$ nota). Por outro lado, as coisas costumeiras que se faziam antes deixam de acontecer, como não precisar mais dizer à mãe que ele está doente $\left(12 / 11 / 77,1^{\text {a }}\right.$ nota $)$. Ao viver sem a mãe, o eu passa a pensar se amou menos do que pensava $\left(28 / 11 / 77,1^{\text {a }}\right.$ nota $)$ e surge, assim, a consciência de que há uma outra existência natural, funcional, mesmo que a lidar com a presença da ausência (28/11/77, 2 ${ }^{\text {a }}$ nota); em crise, Barthes reconhece que tem uma nostalgia, um querer estar distante dos outros em prol de quem permanece vivendo nele: maman (3/12/77), a mantê-la em sua memória dizendo como viver (3/11/77), sentar (9/11/77), vestir /6/3/78).

Essa vontade nostálgica se perfaz também com a compreensão de que ela não mais existe, ela não mais existe, totalmente e para sempre, uma condição sem significado (7/12/77, $1^{\text {a }}$ nota) - ressurge aqui o semiólogo, e com a noção de que ele precisa buscar um sentido para sua vida (11/12/77). Em outra casa (da cunhada Rachel e de seu irmão Michel), ele se apercebe que precisa estar na casa dela (27/12/77). Estar com os outros significa sentir-se absolutamente sozinho (8/1/78), em desacordo e impaciente com eles, com sua ansiedade por vida, com o universo deles $\left(16 / 1 / 78,1^{\text {a }}\right.$ nota). Seu novo estar é complexo, pois pensava que assumiria pela ausência dela uma qualidade perfeita de bondade $\left(12 / 2 / 78,1^{\text {a }}\right.$ nota $)$ e de força $\left(18 / 2 / 78,2^{\text {a }}\right.$ nota $)$, mas isso não acontece - ele se torna menos nobre, menos generoso, mais frágil, pela sensação de abandono; ele quer viver de acordo com os valores dela, mas se torna o seu contrário (31/12/78). A memória do gosto e o silêncio cúmplice, especialmente nas tarefas domésticas, como se fosse uma conversa $\left(18 / 8 / 78,1^{\text {a }}\right.$ nota $)$, se aliam na manutenção do outro ausente $(11 / 8 / 78)$, a ponto de manter flores no mesmo lugar e desejar não viajar para que as flores estejam sempre frescas $\left(18 / 8 / 78,2^{a}\right.$ nota). Viajar é estar longe dela, mais ainda difícil porque ela já não vive, ela que é não mais que a mais íntima expressão do cotidiano (é importante observar o uso do tempo presente na descrição de Barthes, como se a mãe permanecesse). Em autoanálise, tratando de sua depressão, afirma que não pode suportar algo que ele possa usar como substituto de sua mãe, e que isso se dá da forma menos penosa no apartamento, onde há uma espécie de prolongamento da sua vida com ela $\left(21 / 8 / 78,1^{\text {a }}\right.$ nota). Finalmente, a expressão maior do sehnsucht creio es- 
tar no registro de seus sonhos, exclusivamente com ela e sobre ela, que ele acredita acontecer para vê-la, acreditar que está viva, mas outra, separada dele $\left(18 / 3 / 79,2^{\text {a }}\right.$ nota $)$.

\section{Futuromania}

A ideia de futuromania, enquanto angústia ou busca pela saída da tarefa do luto, é proposta por Barthes logo no início do diário, quando anota haver uma construção furiosa do futuro (mudar mobília etc.) tão logo alguém morre ([27/10/77], $3^{\text {a }}$ nota); ocorre mesmo em breves instantes, como ao levar o corpo para o seu local definitivo e perceber o cheiro doce da chuva, "algo como um gosto de vida" (28/10/77); chegará o momento também em que todos os compromissos éticos com a morta se perfazem, a lembrar o que move Antígona: o enterro em Urt, o túmulo, as coisas dela doadas $\left(9 / 6 / 78,4^{\text {a }}\right.$ nota $)$, separar dolorosamente aquilo que permanece $(11 / 6 / 78)$, como as fotos da mãe Henriette Barthes, que serão a base para a escrita de La Chambre Claire. Interessantemente, em uma nota escrita quase um ano após o início do diário, Barthes registra a modéstia de sua mãe, com poucos itens de posse, como se quisesse que não houvesse um livrar-se de coisas quando de sua morte (3/10/78).

Por outro lado, essa futuromania se traduz pela necessidade de também dar seguimento às coisas diárias $\left(31 / 10 / 77,3^{\mathrm{a}}\right.$ nota), distrair-se (falar, "ter de fazer uma piada" ou "au besoin plaisante") (1/11/77, $2^{\text {a }}$ nota), divertir-se ("saia, divirta-se") (3/11/77), rir com os amigos e fazer planos $\left(6 / 11 / 77,2^{\text {a }}\right.$ nota); mas, para isso, precisa coragem ou vontade de viver (10/11/77, $1^{\text {a }}$ nota), um estar sujeito aos "sopros de vida" ou "bouffés de vie" (15/11/77, 2a nota), propenso aos desejos, mesmo que datem de um outro tempo (16/11/77), quando a memória das palavras ditas por ela não o fazem mais chorar, ainda que haja um horror nessa sensação (19/12/77, 2 a nota). Essa sensação de futuromania ao longo da tarefa do luto não está sempre presente, mas ele se mantém vigilante, esperando pelo início de uma sensação de vida (8/12/77); ao par do desespero, existe um desfrutar do apartamento bem ajeitado $(4 / 11 / 77)$.

O luto não existe sozinho, outras coisas devem acontecer - a sociedade assim o exige e recomenda, mesmo que nesses momentos se sofra mais (19/03/78); o tempo ou a atividade dos outros não para, o que dá a Barthes a sensação de impaciência $\left(16 / 1 / 78,1^{\text {a }}\right.$ nota); as exigências dos outros logo após a morte de maman lhe ensurdecem por sua continuidade (15/6/78). 
Outro ângulo desse conflito é a sua necessidade vital de solidão por conta do luto em contraste com a necessidade não menos vital de amigos (3/8/78). Seu sofrimento poderá acabar quando puder escrever, algo desejado e para o que ele se prepara (8/5/78); ele também se apercebe que as coisas diárias e triviais (que chama de vida estúpida) são um sinal da luta da vida contra a morte e que tal luta leva a uma vida inteligente (20/6/78). Isso se perfaz no esforço extenuado de um grande projeto de escrita por conta da morte de sua mãe, que sinaliza também uma alteração na confiança nele mesmo (17/9/78), que se concretiza na escrita de La Chambre Claire no período de abril a junho de 1979.

A morte transforma o eu, que se vê distante daquele que se foi; se, por um lado, há o surgimento do eu-e-o-outro (especialmente pela memória e pelo dever ético), surge outro eu, que se descobre e se postula diferente nessa descoberta. Uma sensação complexa é a da sua relação com o mundo, do seu papel diante dos próximos, aquilo que resulta da política da amizade (ou do vínculo com as poucas pessoas amadas): o próprio ser diante da sua morte como desimportante (30/10/77) e como solução (4/11/77, $3^{\text {a }}$ nota), a contemplar que lhe falta a Razão de temer pela vida de alguém (2/4/78), a sensação de vazio ou de frieza/anestesia e a percepção diferenciada e aguda do mundo e das pessoas ( $31 / 10 / 77,4^{\text {a }}$ e $5^{\mathrm{a}}$ nota), o ser pouco generoso $\left(12 / 2 / 78,1^{\text {a }}\right.$ nota $)$. Barthes percebe, também, a diferença de suas atitudes, pois perdeu alguém, como uma perda infinitamente mais séria, em relação a outro (FW) que perdeu alguém, mas esse alguém continua vivo $\left(9 / 6 / 78,1^{\text {a }}\right.$ nota $)$.

Esse novo eu busca o seu próprio espaço, que permite, aos poucos, que se afaste do evento: o apartamento aquecido, limpo, bem iluminado, agradável (4/11/77, $4^{\text {a }}$ nota); certa posse de liberdade (2/3/78), que acaba por ser diferente na ausência de maman (18/4/78); a decisão de mudar o seu próprio gosto no vestir $(6 / 3 / 78)$. O reconhecimento que tinha por meio dos livros parece precisar ser novamente instituído, no caso, por meio de um livro sobre sua maman, a construir-lhe um monumento que seja reconhecido (5/6/78).

Esse descobrir-se não fica impune; por paradoxo, quanto mais se vê longe, "do lado de fora," distante dela, a vivenciar prazeres e distrações, quando o mundo lhe diz que ali estão todas as coisas para que possa esquecer, menos se esquece dela (27/4/78, $1^{\text {a }}$ nota). Esse "eu" acreditava em algo, logo pensava no futuro, uma liberação, a sobrevivência dela como modelo; no entanto, 
surge o contrário, o apego a pequenas coisas, o concentrar-se em si mesmo sem se relacionar, indiferente aos outros nas suas palavras: "la 'sécheresse de coeur' - l'acédie" ou a "secura do coração', a acédia” (27/4/78, 2a nota), uma impotência para o amor, uma irritabilidade (1/8/78, $4^{\mathrm{a}}$ nota). A acédia vem exatamente da impossibilidade de ter alguém com valor suficiente para ter a coragem de não resistir ao amor. A descoberta solidão nova (oriunda da morte da mãe) deixa-o, lamentavelmente, mais sozinho e mais abandonado no espaço de seu trabalho onde ela não tinha presença, espaço de retiro ao qual ele antes não recorria diretamente (10/5/78, $2^{\text {a }}$ nota). Sua vinculação a outros também se faz diferente e distante por conta da infusão que percebe ter dos valores éticos e estéticos de sua mãe (7/3/79).

O primeiro contato com os outros, enquanto coletivo, se dá no momento do velório (27/10/77, $9^{\text {a }}$ nota), outros momentos públicos são registrados como oportunidade de ensimesmamento (19 e 23/11/77). Nos instantes de contato com os amigos ou conhecidos, ele se retrai, sofrendo por talvez perceberem-no retraído por discordar do assunto (3/12/77); embora todos sejam extremamente amáveis, sente uma "abandonite" (8/1/78). Em Urt, onde sua mãe está enterrada, sofre por estar em outros lugares, mesmo que familiares, que não o apartamento, (27/12/77), um sentimento de abrasão $(1 / 1 / 78)$. O mundo o deprime, os outros aumentam sua tristeza, sua confusão, sua irritação (18/5/78); a sociabilidade necessária e demandante reitera a vaidade do mundo onde ela não mais existe (22/11/78). Esse mesmo mundo, sem que ela esteja ali para protegê-lo, exige uma nova iniciação, a miséria própria de um nascimento $(23 / 12 / 78)$, no caso, nascimento de um novo eu após a morte dela.

\section{Trauer, deuil, luto}

Como se poderia esperar, a tarefa do luto é o que mais aparece em seu texto, tanto na discussão sobre o significado do luto, quanto na percepção do sofrimento, da melancolia, da depressão, e até mesmo a fazer uma crítica particular do luto no contexto psicanalítico. Seu testemunho, pormenorizado, profundamente reflexivo, por vezes antológico, serve como guia de compreensão das emoções do luto e das ações resultantes, na particularidade pessoal. Não há, e nem poderia haver, uma compreensão do luto como atitude geral ou como uma disposição social; em Journal de Deuil, prevalece o discurso ético, individual, familiar, em relação unívoca. Barthes está acima das percepções comuns, usuais e costumeiras (até mesmo de um orde- 
namento psicanalítico) acerca do luto, não por ser quem era, mas por uma fineza de análise íntima e da profundidade franca de seus sentimentos, como quando, em contraste com a noite de núpcias, pergunta sobre a primeira noite de luto (26/10/77).

A intensidade da perda varia em cada um de nós; por outro lado, Barthes entende que é impossível medir o tamanho de seu efeito em alguém (27/10/77, $7^{\text {a }}$ nota), embora ele tente definir, por meio de um memorando para o dicionário, a medida do luto: 18 meses para estar de luto pelo pai, pela mãe (29/10/77), na tradição social orgânica, que remonta à antiguidade clássica (KURTZ; BOARDMAN: 1971; ALEXIOU, 1974; LORAUX, 1981) e que determina e codifica o período aceitável para a exteriorização da dor do luto familiar (24/6/78); o tempo seria o vetor suavizante do luto, mas, para Barthes, apenas a emotividade do luto passa com o tempo (20/3/78), porém o sofrimento permanece $\left(22 / 3 / 78,1^{\text {a }}\right.$ nota). A perda se manifesta como pesar por ela, uma dor diante da ausência; no caso da perda por morte, o velório é o seu início formal (27/10/77, $9^{a}$ nota). Intuitivamente talvez, Barthes discute o seu luto como algo emocionalmente feminino e "superficial" no sentido de estar apenas na superfície e não como ligeiro e pouco importante (encontrável com facilidade nas tragédias gregas, algo como descrito por Titus Livius como luto público ou a publica maestitia, em seu Livro II.7 de Ab urbe condita), contrário à imagem séria de um pesar "verdadeiro" (1/11/77, 2a nota); afinal, do luto dos homens se espera uma reserva dos sentimentos (SUTER, 2008).

O seu luto parece que no início será caótico ( $2 / 11 / 77,2^{\text {a }}$ nota), com uma oferta de iluminação (4/11/77), sem enfrentamento empírico, aparentemente controlado, que parece sinalizar o seu pouco sofrer (5/11/77). Por vezes, embaraçado e um tanto culpado, percebe o seu luto como mera suscetibilidade/tendência à emoção, talvez expressão de sua vida toda: uma emotividade $\left(10 / 11 / 77,3^{\text {a }}\right.$ nota), dilacerado ou enfermo (15/11/77). Ele percebe o luto como um conjunto de unidades; cada uma delas tem a sua totalidade, mesmo que dispostas em camadas, uma espécie de esclerose $\left(1 / 11 / 77,1^{\text {a }}\right.$ nota); também, não é uma opressão avassaladora, mas uma disponibilidade dolorosa (8/12/77), uma indisposição, uma situação sem chantagem possível (9/12/77). Algo que afeta Barthes inicialmente e que depois ele resolve pela escrita do luto (ou do sofrimento) é a sua "indescritibilidade", resultante da sua falha em realizar a histerese do luto, ou seja, de retardar a sua resposta $(29 / 12 / 77)$. Para ele, na morte do ente amado, há uma fase aguda de narcisismo, pois se sai da doença, da serventia; depois, gradualmente, a liberda- 
de assume um aspecto pesado, o narcisismo cede espaço para um egoísmo tristonho, uma ausência de generosidade ( $1 / 8 / 78,5^{\text {a }}$ nota).

O mundo, antes despertado pelo desejo, torna-se desolado e deplorável (16/11/77, $2^{\text {a }}$ nota); em outro instante, Barthes pergunta a razão de um dia repleto de acidentes com um efeito de agouro se assemelhar tão bem ao luto (19/11/77, $3^{\text {a }}$ nota). A buscar um sentido para seu luto, quando está na Igreja de Saint-Sulpice, em Paris, pergunta se o luto não deveria levar à ausência de desejo (9/6/78, $2^{\text {a }}$ nota). Com certeza, tanto quanto no amor, há no luto algo de inoportuno, de uma irrealidade, que afeta as coisas do mundo (18/5/78, $1^{\text {a }}$ nota). A noção do espaço e da condição emotiva do deixado/ sobrevivente (Barthes parece se sentir tanto deixado quanto sobrevivente) se torna especialmente aflitiva, pois onde está infeliz resultaria que em outro lugar estaria feliz, mas essa proposição é a armadilhas dos contrários das coisas que não se tornam contrárias; em Urt, está infeliz e deixar o lugar não o torna feliz (1/9/79).

O luto em Barthes tem seu caráter de descontinuidade (que eu diria de uma qualidade senoidal), é terrível (26/11/77), errático, resistente ao aceitável conceito psicanalítico de sujeição ao tempo, sem retirar coisa alguma e sem diminuir tampouco (29/11/77, $2^{\text {a }}$ nota), não contínuo, mas imóvel $\left(9 / 6 / 78,3^{a}\right.$ nota). Confrontado com a ideia de que o luto pode ser reduzido ao conhecimento próprio na esteira de Kierkegaard em Frygt og Bæven [Temor e Tremor] (1843), Barthes afirma que não aceita que seu sofrimento possa ser reduzido, generalizado (29/11/77, $2^{\text {a }}$ nota): seria como lhe roubassem o sofrimento. $\mathrm{O}$ ato de produção do conhecimento do luto, nesse caso, parece ser um esvaziamento do ser. Na nota seguinte do mesmo dia, Barthes entende que o sujeito (ele) está apenas presente, não apenas no presente, como se fosse um estado irredutível; também o qualifica de imutável e de esporádico porque ele não é contínuo (18/2/78, $1^{\text {a }}$ nota). A solidão no trabalho, onde sua mãe não tinha presença, é uma metonímia do Luto, do Abandono (10/5/78, $2^{\text {a }}$ nota).

A depressão em Barthes vem das profundidades do desespero, ao perceber que ele não pode se salvar do apego que tem à escrita, mesmo na sua perfeição, somente um escárnio (21/11/77, $4^{\text {a }}$ nota). No luto, interrupções mundanas fazem a depressão aumentar; aquelas que levam ao silêncio fazem com que a ferida do luto adentre a esfera mais elevada do pensamento $\left(18 / 2 / 78,1^{\text {a }}\right.$ nota). Referido por ele como satori (súbita compreensão e um estado de consciência obtido através da iluminação no Zen Budismo), igua- 
lado aos esmorecimentos do luto (sem data, entre 18 e 21/4/78), é no silêncio que há uma espécie de sublimação, de reconciliação, de estabelecimento de uma interiorização profunda sem abatimento (12/8/78).

A morte de sua mãe é a coisa na vida dele que não teve uma resposta histérica, neurótica, a resposta é raramente visível aos outros, nada teatral; em contraste, conduz sua depressão, levando ao isolamento social - a conclusão dele é intrigante, a resposta neurótica teria sido menos infeliz, o não neurótico não é bom, não é a resposta certa (18/5/78, $2^{\mathrm{a}}$ nota). Não há nele sinais de um luto internalizado, o que seria a obtenção de uma internalização absoluta; daí a sua dificuldade, vez que nega o luto (24/6/78). Sua nota sobre a verdade bárbara e idiota do materialismo que nega a crença nas almas, na imortalidade das almas (13/7/78), revela o efeito cáustico da morte da mãe no homem lógico e racional, verdadeiro conflito ético.

Mais de um ano depois da morte de sua mãe, a acédia permanece, através de uma amargura no coração, da propensão a ciúmes, da falta de amor próprio; ele reconhece também um mecanismo clássico do luto - período de autocomiseração $\left(29 / 12 / 78,1^{\text {a }}\right.$ nota $)$. Um pouco depois, registra a economia do luto nos últimos 18 meses (lembrando que esse é o prazo que ele definiu como viável ou recomendável), algo imóvel, nada espetacular, que o manteve separado (isolado) pelas necessidades do luto; algo que ele pensa em finalizar/fechar com um livro (15/3/79).

Barthes se apercebe que o luto (talvez tarefa) não é o que sente, não está enlutado, mas, sim, sofrendo $\left(30 / 11 / 77,1^{\text {a }}\right.$ nota $)$. A cada momento de sofrimento, parece que surge novamente a noção de que o luto se torna efetivo, porque totalmente intenso (30/11/77, $3^{\mathrm{a}}$ nota), com velocidade de cruzeiro (22/3/78); a cada início de pesar, ele chora (12/6/78, $2^{\text {a }}$ nota). Ele iguala sofrimento a luto, a partir de Proust explicado por George D. Painter (5/7/78). O ritmo do sofrimento é individual (18/7/78), sendo que no sofrimento ele se encontra alegre, tudo o que não for viver o sofrimento é insuportável para ele $\left(31 / 7 / 78,1^{\text {a }}\right.$ nota $)$; nada pede a não ser viver no seu sofrimento $(31 / 7 / 78$, $2^{\text {a }}$ nota). Seu sofrimento é suportável, inexpressável, mas ao mesmo tempo pode ser colocado em palavras; homem da cultura de palavras, capaz de apotropismos, ele percebe que ao permitir a língua a existência da palavra "intolerável" (adjetivo que ele usa para descrever o olhar a foto de sua mãe), é possível certa tolerância $\left(1 / 8 / 78,1^{\mathrm{a}}\right.$ nota).

Aqui se faz necessário apontar uma reserva de Barthes em relação à explicação freudiana da tarefa do luto. Ele quer evitar o luto como palavra, 
transformando-a ou sentindo nele a prevalência do sofrimento; não quer que se diga luto, "é muito psicanalítico" (30/11/77, $1^{\text {a }}$ nota). Para Freud, o luto é uma tarefa de reconstrução de foco - o deixado precisa, paulatinamente, se desvincular do morto, transformando-o em objeto não mais de desejo; a acomodação resultará no restabelecimento das ligações do deixado com os outros, que estarão pautadas pela energia da libido. A reserva de vários teóricos da área da psiquiatria em relação ao modelo freudiano está a mais das vezes na proposta de extensão do conceito a outras perdas (BRETHERTON, 1992); outras particularidades estão vinculadas à noção do ego e do mundo interno (SIMON, 1984). O luto para Barthes é estático, não diminui; ele se sente mais próximo da mãe do Le journal d’un curé de campagne (1936), de Georges Bernanos, do que do esquema freudiano (1/8/78, $4^{\text {a }}$ nota).

$\mathrm{O}$ usar das palavras permite a ele afastar ou diminuir a dor do sofrimento; quando não escreve (sobre) o seu sofrimento, ele se torna mais forte, migrando para o reino do eterno (4/12/78). Em atitude dialógica com Proust, define que o seu sofrimento não é o superlativo de dor, de abandono, um tipo abstrato, em verdade, é um novo tipo (10/8/78, $1^{\text {a }}$ nota). Ainda, o sofrimento é uma forma de egoísmo, pois só ele importa (21/8/78, $3^{\text {a }}$ nota), é a impossibilidade do conforto em qualquer lugar, aquilo definido por Pascal como "aflição do homem" ou "misére de l'homme" (1/9/79, $3^{\text {a }}$ nota).

Para Barthes, é possível um segundo luto, resultante não da supressão do sentimento, a partir da noção estúpida da passagem do tempo, mas da transformação do luto, da mudança do estado estático (onde sempre acontecem as mesmas coisas) para um estado fluido (13/6/78, $1^{\text {a }}$ nota); esse segundo luto ocorre nele aos oito meses desde a morte de sua mãe (14/6/78). O segundo luto é uma liberdade desolada, fatal, sem uma ocupação de valor; o primeiro luto é uma liberdade falsa (17/6/78). Ele se opõe profundamente à noção comum (doxa) do luto como algo vinculado ao tempo, que amadurece, que chega a eclodir, no qual certas atitudes podem ser prematuras; ele insiste na sua imobilidade, e não como um processo, e argumenta que voltou de Urt e ajeitou o apartamento, que agora pensa em escrever um livro sobre as fotos de maman e que tais atitudes podem ser consideradas pelos outros como prematuras (16/6/78). No momento em que lidou com as coisas de sua mãe que não seriam doadas (11/6/78), olhou as fotografias; retornou a elas dolorosamente dois dias depois, devastado especialmente pela foto da mãe como criança no Jardim de Inverno de Chennevières (motivo principal de La Chambre Claire), novamente começar [o luto] sem descansar, talvez 
como se fosse Sísifo. Mais dois dias, ele se apercebe que há o começo do luto verdadeiro, junto com um sofrimento cruel.

\section{Morte, imortalidade, literatura}

Em Barthes, a morte está marcada por palavras: "é impossível!", "por quê, por quê?", "Para sempre" (7/12/77), lembrando a fase da raiva definida por Kübler-Ross (1969), quando o sujeito se vê angustiado, a procurar as razões de ter sido escolhido. A imortalidade o deixa perplexo, por um pirronismo (27/10/77, $6^{\text {a }}$ nota), por sua impossibilidade (27/10/77, $8^{\text {a }}$ nota), afinal todos têm-de-morrer, pois que mortais $\left(16 / 11 / 77,1^{\text {a }}\right.$ nota $)$. Depois da morte do ente amado, a raiva existe, com certeza; outro sentimento é aquele da falta de propósito, de objetivos. Daí, as perguntas sobre a cura do luto, da depressão, como se não houvesse sentido, para qual vida $\left(27 / 10 / 77,5^{\mathrm{a}}\right.$ nota). $O$ pensar na morte de sua mãe faz com que ele tenha hesitações repentinas e fugidias, breves esmorecimentos, abraços pungentes, embora vazios - neles, como essência, a certeza do Definitivo (21/4/78). Barthes sofre de um medo da concretização do que aconteceu (a morte da mãe) - aceitar a concretização significa aceitar o Definitivo, o imutável (10/5 e 9/6/78), a catástrofe (6/10/78), conceito que leu na edição francesa do texto "Fear of Breakdown" ou "Medo do Surto Psicótico" (1963), de Donald Woods Winnicott.

Geralmente, temos um conhecimento da morte emprestado da experiência alheia, mesmo caso de Barthes; somente através do luto de sua mãe, ele se apropria do conhecimento da morte, da sua radical e nova domesticação (1/5/78). Em essência, a experiência do luto se torna a aproximação com a morte, como se nada mais houvesse entre ele e o perecimento (28/5/78); entretanto, não há nele o desejo do suicídio (13/6/78). Nada obstante, torna-se suave para ele, através da morte da mãe, a aceitação da mortalidade de todos os homens (8/10/78), uma consciência do memento mori, em razão da não discriminação da morte em relação a todos os seres vivos.

Essa ideia do absoluto, do estar morta "para sempre", do completamente o atormentam, em razão da violência que tal ideia carrega, insuportável, impossível, e que acarreta o convencimento da própria morte em algum tempo futuro, também para sempre, também completamente. De fato, em uma das mais longas notas (6/10/78), é o MEDO que se torna o elemento central de sua experiência. As perguntas angustiadas vêm do medo, antes da morte futura e da perda, depois de sua própria morte (embora morto, poderá encontrá-la), mas principalmente da aceitação da perda, o que o 
leva a buscar um lugar onde esteja protegido do medo. Nesse momento, ele ordena a si mesmo o exorcismo do medo, exterminar o que o impede de escrever a obra sobre maman. Esse monumento póstumo, a obra, lhe deixa também a desejar que não haja uma posteridade dele; ele chega a perguntar "escrever para ser lembrado?" (12/4/78), vez que não haverá sobreviventes ou deixados, vez que a memória de sua mãe não sobreviverá além dele $\left(21 / 8 / 78,2^{\text {a }}\right.$ nota $)$.

Ao par das referências a Tolstoi e a outros textos, além de menções de filmes e de músicas (principalmente via rádio), sobressai em Journal de Deuil a figura de Marcel Proust, cartas e outros escritos. É nele que Barthes encontra várias explicações para suas emoções: a iluminação através do luto $\left(4 / 11 / 77,1^{\text {a }}\right.$ nota, quando parece que ele se refere à oferta das cartas de Mme. de Sevigne feita por Bathilde Amédée ao neto, narrador de $\bar{A}$ la recherche $d u$ temps perdu), a diferença entre luto e sofrimento, esse que distorce tudo (5/7/78), a contradição entre a memória e o nada (sem data, entre 13 e 18/7/78) em referência a "cette incompréhensible contradiction du souvenir et du néant", em "Les intermittences du coeur" em "Les intermittences du coeur" (PROUST, 1954: 2.769), na alegria encontrável na miséria após a morte da mãe de Proust (29/7/78, $1^{a}$ nota), a ponto de Barthes desejar viver no sofrimento $\left(31 / 7 / 78,2^{\text {a }}\right.$ nota). A literatura é o sítio (1/8/78, $2^{a}$ nota) onde encontra o seu lugar de enfrentamento, onde se engasga com as verdades, com tudo o que Proust escreve sobre doença, coragem, a morte da mãe, o sofrimento (1/8/78, $3^{\text {a }}$ nota). Em Contre Sainte-Beuve, de Proust, surge por símile a compreensão do sofrimento em relação ao conceito proustiano de Beleza (10/8/78, $1^{\text {a }}$ nota); Barthes destaca o sentimento de Proust em relação à mãe na compreensão da postura religiosa, católica e jansenista da mãe de Proust e protestante da mãe de Barthes (10/8/78, 2a nota). A emoção da finitude absoluta, do Definitivo, o faz pensar que deve procurar outro caminho.

\section{La chambre claire}

A construção do livro sobre maman resulta de um longo processo de compreensão do luto. Ao começar a fazer o Journal de Deuil, colocando os sentimentos em palavras, Barthes questiona-se tanto positivamente ao reconhecer um possível valor nas notas (27/10/77, $4^{\text {a }}$ nota), quanto negativamente, como se resultassem de sua banalidade individual (29/10/77, $4^{\text {a }}$ nota); a recusa da expressão em palavras se dá pelo medo de fazer literatura do seu 
sofrimento, embora admita que a literatura tenha origem nas verdades expressadas a partir das emoções $\left(31 / 10 / 77,1^{\text {a }}\right.$ nota).

Diz-se que as grandes crises (amor, luto) precisam ser li(qui)dadas lentamente, para que se possa delas emergir; a tarefa do luto para Barthes pode ser eliminada somente na e pela escrita $\left(31 / 5 / 78,2^{\text {a }}\right.$ nota), é quando ele conquistaria a liberdade, que planeja através da escrita de um livro sobre fotografia (23/3/78); é pela obra sobre maman que ele pensa que construirá o monumento necessário de memória da vida dela, memento illa vixisse (12/4/78), que a tornará reconhecida (5/6/78); sua postura é tão forte que, instintivamente, faz uma oração pedindo que conclua o livro Photo-Maman $\left(9 / 6 / 78,2^{\text {a }}\right.$ nota $)$.

A partir da foto do jardim de inverno, sua mente busca incessantemente significados. Ele se declara impotente para dizer o óbvio, e conclui em frase nominal: "o nascimento da literatura" ( $24 / 7 / 78,2^{\text {a }}$ nota), de certa maneira reforçando a noção que expressou logo depois da morte de sua mãe: a literatura nasce da verdade das emoções. O tempo (que ele precisava negar) passou e ele consegue, finalmente, exprimir em palavras o seu sofrimento $\left(1 / 8 / 78,1^{a}\right.$ nota). Olhar a foto é algo muito doloroso, intolerável, pois a imagem entra em conflito com os ignóbeis combates da vida dele - a imagem é um juiz, não a identidade, mas a virtude que existe, rara expressão, na identidade (29/12/78). A foto da mãe criança, em sua mesa, se torna a essência, a virtude, a memória capaz de mantê-lo íntegro, novamente diante da sua presença ausente, capaz de apreender o ser em equilíbrio da mãe ou capaz "de saisir le tel de son être", que ele tenta descrever em palavras, inundado pela bondade dela (20/1/79).

Esse sofrimento e sua concretização em palavras se fazem, pelo menos em uma faceta, na compreensão da mãe, a partir do final do conto “Отец Сергий [Padre Sergei]” (1890), de Tolstoi, como aquela dotada de uma santidade própria da não-linguagem; paradoxalmente, ele, tão "intelectual", vive obcecado com a metalinguagem (25/10/78). Sua mãe merece o refúgio que ele propõe, a escrita, a criação da literatura, único espaço da nobreza, pois "maman era nobre" (18/1/79). Depois da escrita de La Chambre Claire, feita entre abril e junho de 1979, as tentativas todas de realizar o projeto falham (que parecer ser o de Vita Nova, alinhavado como roteiro em 30/11/77), como se tivesse acontecido o grande julgamento de seu luto, aquele adulto, decisivo (22/7/79), e a dor permanece: "ainda tão intenso, mas mudo, luto, sofrimento..." (1/9/79, $1^{\text {a }}$ nota). 


\section{La parole existait déjà}

Não há dúvida sobre a vinculação umbilical entre Journal de Deuil e La Chambre Claire, espaços que precisam e devem ser vistos como estruturas complementares. A gênese de um está sem dúvida no outro, e ambos têm a qualidade do fragmentário e da possível ficcionalidade. A proposição de abertura desse texto se fez com Antígona, a bem da verdade com a fala de Ismênia. Em Barthes, estão, Ismênia e Antígona, no conflito ético em relação à sua mãe, a lidar com a phillia e com a polis. Se há uma exigência do mundo, que diz do tempo, da tarefa do luto, da necessidade de se vincular, de voltar ao mundo dos outros, há também uma tarefa, um expressar impossível, um respeito, uma tentativa de fidelidade e de infidelidade póstuma.

As análises teóricas do luto não contemplam, aparentemente, enquanto modelos, o processo vivido por Barthes. Em James William Worden (1991), as fases do processo do luto são: aceitar a realidade da perda; trabalhar a dor advinda da perda; ajustar-se a um ambiente em que o falecido está ausente; transferir emocionalmente o falecido e prosseguir com a vida. Já Catherine M. Sanders (1999) estabelece os seguintes passos: choque; consciência da perda; conservação-retirada; cura; renovação. Mesmo no inovador conjunto de ideias sobre o luto complicado de Therese A. Rando (1993), o testemunho de Barthes resulta não de uma e, sim, da junção de algumas das conjunturas propostas, especialmente com a última: luto ausente, luto atrasado, luto inibido, luto distorcido, luto conflituoso, luto inesperado, luto crônico.

Talvez seja possível dizer que o Journal de Deuil é uma elegia confessional, por haver nela uma ansiedade lírica, que retarda a consolação e impede mesmo o aprendizado através da katharsis. Entretanto, contrário às expectativas gerais da proposição elegíaca, não há um final de regozijo e de reafirmação (como uma elegia falha). $\mathrm{O}$ círculo não se fecha, mesmo com a escrita de La Chambre Claire, que, em tese, seria a sensação do fim, o retorno aos outros. Aqui o grande complicador, pois o eu elegíaco em Barthes, percebido em progressão com o eu que era, o eu-e-o-outro, o eu que escreve e que se faz próximo dos outros, não se transforma em um "eu futuro", um eu-sem-o-passado. Em Journal de Deuil, Barthes registra o papel aflitivo da presença da ausência de sua mãe, cuja forma de enfrentamento se amolda através da construção do monumento a sua mãe, como Antígona quis dar o túmulo a Polinice, de maneira que cumprisse o seu compromisso ético com o irmão. Pensado como Photo-Maman, La Chambre Claire é esse túmulo, esse monumento, essa impossibilidade finalmente possível. Caberá, assim, 
que se faça em outro momento a leitura de La Chambre Claire para perceber quanto desta está no Journal de Deuil.

O dilema enfrentado por Barthes se configura entre o que se espera dele, o que os outros querem dele, o que ele mesmo havia pensando antes sobre a perda futura da mãe, e o conflito ético, póstumo, da memória da mãe. A escrita de Journal de Deuil é como se ele pudesse retirar dele a memória da mãe, tornando-a perene e imortal até o ponto possível do conceito de imortalidade. Se é possível articular tanto uma progressão da tarefa do luto em Barthes, na circunstância do sofrimento e seus dois lutos, há de pensar que, em essência, embora o luto lhe pareça estático, imóvel, inabalável, é através da autoanálise, do mecanismo de expressão (da metalinguagem) por palavras que ele chega a purgar o luto que nele está integrado. A palavra é a construção controlada da emoção, realizando isto (no sentido de ter existência concreta) por meio de um ato cerimonial, ordenando-a como se pudesse, através dela (da palavra organizada), efetivar a liturgia ética necessária e pretendida enquanto dever moral. A palavra de Henriette Barthes era a não-palavra, a não-linguagem, que passa a estar integrada na pessoa de Barthes, onde está o espaço da metalinguagem; o longo duelo entre os dois mundos se perfaz definitivo no momento da concretização do livro-monumento, um longo epitáfio, seu compromisso (29/3/79) realizado, finalmente a sua memória de maman expressa em palavras eternas enquanto existirem. Voilá.

\section{Referências Bibliográficas}

ALEXIOU, M. The Ritual Lament in Greek Tradition. London: Cambridge U P, 1974.

BARTHES, R. Journal de Deuil. Texto estabelecido e anotado por Nathalie Léger. Paris: Seuil, 2009.

. La Chambre claire: Note sur la photographie. Paris: Gallimard, 1980.

BRETHERTON, I. The origins of attachment theory: John Bowlby and Mary Ainsworth. Developmental Psychology, v. 28, p. 759-775, 1992.

COIXET, I. Elegy. Atores: Penelope Cruz, Ben Kingsley e Dennis Hopper. Samuel Goldwyn Films, 2008.

DERRIDA, J. Les morts de Roland Barthes. Poétique, v. 47, p. 269-92, 1981. 
. Politiques de l'amitié. Paris: Galilée, 1994.

DERRIDA, J. et al. In Memoriam. Yale French Studies, n. 69, p. 3-21, 1985.

FREUD, S. Trauer und Melancholie. Internationale Zeitschrift für Ärztliche Psychoanlyse, v. 4, n. 6, p. 288-301, 1917.

KIERKEGAARD, S. Frygt og Baven [Temor e Tremor]. Kjøbehavn: Reitzelske, 1895.

KÜBLER-ROSS, E. On Death and Dying. New York: MacMillan, 1969.

KURTZ, D.; J. Boardman. Greek Burial Customs. London: Thames and Hudson, 1971.

LORAUX, N. L'Invention d'Athènes: histoire de l'oraison funèbre dans la cité classique. Paris: La Haye, 1981.

LEVINAS, E. Autrement quêtre ou au-delà de E'essence. Dordrecht: Kluwer Academic, 1996.

PAINTER, G. D. Proust: The Later Years. Boston: Little, Brown, 1965.

PROUST, M. À la Recherche du Temps Perdu. 3 v. Paris: Gallimard, 1954.

RANDO, T. A. Treatment of Complicated Mourning. Champaign: Research Press, 1993.

RICOEUR, P. De l'Interprétation: essai sur Freud. Paris: Seuil, 1965.

ROTH, P. The Dying Animal. Boston: Houghton Mifflin, 2001.

SANDERS, C. Grief. The Mourning After: Dealing with Adult Bereavement. 2. ed. New York: Jonh Wiley \& Sons, 1999.

SIMON, R. Contribuição ao Estudo do Objeto Interno. Revista Brasileira de Psicanálise, v. XVIII, n. 3, p. 283-300, 1984.

SÓFOCLES. Antígona. Disponível em: <http://www.perseus.tufts.edu/hopper/text?doc $=$ Perseus\%3atext\%3a1999.01.0185> . Acesso em: 9 mai. 2011.

SPARGO, R. Clifton. The Ethics of Mourning: Grief and Responsability in Elegiac Literature. Baltimore: Johns Hopkins U P, 2004.

SUTER, A. Male Lament in Greek Tragedy. Lament: Studies in 
the Ancient Mediterranean and Beyond. New York: Oxford U P, p. 156-180, 2008.

TITO LÍVIO. Desde a fundação da cidade. Disponível em: $<$ http://www.thelatinlibrary. com/livy/liv.2.shtml\#7>. Acesso em: 9 mai. 2011.

TOLSTOI, L. Смерть Ивана Ильича [A morte de Ivan Ilitch]. Disponível em: $<$ http://ilibrary.ru/text/7/index.html\#toc $>$. Acesso em: 9 mai. 2011.

WINNICOTT, D. Psychoanalytic Explorations. London: Karnac, 1989.

WORDEN, J. W. Grief Counseling and Grief Therapy. A Handbook for the Mental Health Practitioner. 2. ed. London: Routledge, 1991. 